\title{
PENINGKATAN PRESTASI BELAJAR PPKN MATERI SISTEM DAN DINAMIKA DEMOKRASI DENGAN PEMBELAJARAN METODE CERAMAH, BELAJAR AKTIF DAN PEMBELAJARAN AUTENTIK
}

\section{Ida Panca Rohyani}

SMA Negeri 2 Babelan Jawa Barat, Indonesia

Email: praptiwiariesti@gmail.com

\begin{abstract}
Abstrak
Permasalahan rendahnya kualitas pembelajaran PPKn di XI.IIS-5 SMA Negeri 2 Babelan berdasarkan refleksi melalui observasi. Guru kurang memberikan konteks keseharian siswa. Inovasi pembelajaran serta media belum dimanfaatkan dengan baik. Data pendukung adalah hasil belajar 69\% siswa yang memperoleh nilai dibawah Kriteria Ketuntasan Minimal (KKM) yaitu 75. Untuk mengatasi permasalahan tersebut dilakukan penelitian dengan menerapkan Pembelajaran gabungan metode ceramah dan metode belajar aktif dengan metode Pembelajaran autentik. Tujuan penelitian ini adalah untuk meningkatkan kualitas pembelajaran yaitu keterampilan guru, aktivitas siswa, dan hasil belajar Siswa Kelas XI.IIS-5 SMA Negeri 2 Babelan. Tujuan penelitian tindakan ini adalah: (a) Mengetahui peningkatan prestasi belajar PPKn setelah diterapkannya Gabungan metode ceramah dan metode belajar aktif dengan metode Pembelajaran autentik pada Siswa Kelas XI.IIS-5, (b) Mengetahui pengaruh motivasi belajar PPKn setelah diterapkan Gabungan metode ceramah dan metode belajar aktif dengan metode Pembelajaran autentik. Penelitian ini menggunakan penelitian tindakan (action research) sebanyak tiga putaran. Setiap putaran terdiri dari empat tahap yaitu: rancangan, kegiatan dan pengamatan, refleksi, dan refisi. Sasaran penelitian ini adalah siswa kelas XI.IIS-5. Data yang diperoleh berupa hasil tes formatif, lembar observasi kegiatan belajar mengajar. Dari hasil analisis didapatkan bahwa prestasi belajar siswa mengalami peningkatan dari siklus I sampai siklus III yaitu, siklus I $(62,86 \%)$, siklus II $(77,14 \%)$, siklus III $(94,29 \%)$. Simpulan dari penelitian ini adalah gabungan metode ceramah dan metode belajar aktif dengan metode Pembelajaran autentik dapat berpengaruh positif terhadap motivasi belajar Siswa Kelas XI.IIS-5, serta metode pembelajaran ini dapat digunakan sebagai salah satu alternatif pembelajaran PPKn.
\end{abstract}

Kata Kunci: PPKn; metode ceramah; metode Pembelajaran autentik

\section{Abstract}

The problem of low quality of VAT learning in XI.IIS-5 Sma Negeri 2 Babelan based on reflection through observation. Teachers don't have an everyday student context. Learning and media innovation has not been put to good use. Supporting data is the result of learning from 69\% of students who score below the Minimum

\begin{tabular}{ll}
\hline How to cite: & Rohyani. I. P., (2021) Analisis Kestabilan Lereng Tambang Timah "XYZ”, Peningkatan Prestasi \\
& Belajar PPKn Materi Sistem dan Dinamika Demokrasi dengan Pembelajaran Metode Ceramah, \\
& Belajar Aktif dan Pembelajaran Autentik, Syntax Idea, 3(10), https://doi.org/10.36418/syntax- \\
& idea.v3i10.1529 \\
& $2684-883 X$ \\
E-ISSN: & Ridwan Institute \\
Published by: &
\end{tabular}


Completion Criteria (KKM) of 75. To overcome these problems, research is conducted by applying combined learning lecture methods and active learning methods with authentic learning methods. The purpose of this study is to improve the quality of learning, namely teacher skills, student activities, and student learning outcomes of Class XI.IIS-5 Babelan State High School 2. The objectives of this action research are: (a) Knowing the increase in VAT learning achievement after the application of combined lecture methods and active learning methods with authentic Learning methods in Students Grade XI.IIS-5, (b) Knowing the influence of VAT learning motivation after applying combined lecture methods and active learning methods with authentic learning methods. This study uses action research (action research) as many as three rounds. Each round consists of four stages: design, activity and observation, reflection, and reflection. The target of this study is students of class XI.IIS-5. Data obtained in the form of formative test results, observation sheets of teaching and learning activities. From the results of the analysis found that the achievement of student learning increased from cycle I to cycle III, namely cycle I (62.86\%), cycle II (77.14\%), cycle III (94.29\%). The conclusion of this study is that the combination of lecture methods and active learning methods with authentic learning methods can positively impact the learning motivation of Class XI.IIS-5 students, and this learning method can be used as one of the VAT learning alternatives.

Keywords: VAT; method of speech; Authentic learning methods

\section{Received: 2021-09-22; Accepted: 2021-10-05; Published: 2021-10-20}

\section{Pendahuluan}

Manusia sebagai komunitas yang memiliki akal dan jiwa dapat menerima ilmu dari proses interaksi yang dilakukan dengan lingkungannya. Dari ilmu yang diperoleh, manusia dapat mengajari dirinya dan juga dapat mengajarkannya kepada orang lain. Banyak kita temukan orang-orang yang bisa mengajarkan ilmu yang dimilikinya kepada orang lain karena mereka pada awalnya belajar dari orang yang mengajarkan mereka. Artinya mereka diajarkan ilmu bagaimana mengajar yang baik. Namun tidak sedikit pula orang-orang yang mampu mengajar orang lain tanpa belajar ilmu mengajar dari guru mereka (Ichsan, 2016).

Mengajar dapat dikatakan sebagai kegiatan menghadirkan suatu lingkungan yang kondusif untuk di lakukannya proses belajar. Lingkungan tersebut merupakan suatu sistem yang terdiri dari komponen-komponen yang saling berkaitan yaitu tujuan yang hendak dicapai, bahan yang diajarkan, guru dan siswa yang saling berintraksi serta sarana dan prasarana untuk menunjang kegiatan tersebut (Rostiani, 2016).

Pada mereka terdapat seni mengajar yang telah dimiliki tanpa proses belajar. Mengajar bukan semata persoalan menceritakan. Belajar bukanlah konsekuensi otomatis dari perenungan informasi ke dalam benak siswa. Belajar memerlukan keterlibatan mental dan kerja siswa sendiri. Penjelasan dan pemeragaan semata tidak akan membuahkan hasil belajar yang langgeng. Yang bisa membuahkan hasil belajar yang langgeng hanyalah kegiatan belajar aktif (Subiyantoro, 2021). 
Proses belajar pada hakikatnyaadalah kegiatan mental yang tidak tampak. Artinya, proses perubahan yang terjadi dalam diri seseorang yang sedangbelajar tidak dapat disaksikan dengan jelas,tetapi dapat dilihat dari gejala-gejalaperubahan perilaku (Nahar, 2016).

Kondisi pembelajaran yang kondusif hanya dapat dicapai jika interaksi sosial berlangsung secara baik, interaksi sosial yang baik memungkinkan masing-masing personil menciptakan pola hubungan tanpa adanya sesuatu yang mengganggu pergaulannya. Lingkungan budaya memberikan suatu kondisi pola kehidupan yang sesuai dengan pola kehidupan warganya. "lingkungan budaya diartikan sebagai pola kehidupan yang dijalankan masing-masing personil dalam kesaharian. Kemudian. dalam mendukung proses pembelajaran yang kondusif sarana dan prasarana adalah hal yang sangat vital dan harus ada (Arianti, 2019).

Apa yang menjadikan belajar aktif? Agar belajar menjadi aktif siswa harus mengerjakan banyak sekali tugas. Mereka harus menggunakan otak, mengkaji gagasan, memecahkan masalah, dan menerapkan apa yang mereka pelajari. Belajar aktif harus gesit, menyenangkan, bersemangat dan penuh gairah. Siswa bahkan sering meninggalkan tempat duduk mereka, bergerak leluasa dan berfikir keras (moving about dan thinking aloud) (Syaparuddin, Meldianus, \& Elihami, 2020).

Khusus dalam pembelajaran PPKn, agar siswa dapat memahami materi yang disampaikan guru dengan baik, maka proses pembelajaran kontektual, guru akan memulai membuka pelajaran dengan menyampaikan kata kunci, tujuan yang ingin dicapai, baru memaparkan isi dan diakhiri dengan memberikan soal-soal kepada siswa (Efansyah, 2018).

Dengan menyadari gejala-gejala atau kenyataan tersebut diatas, maka dalam penelitian ini penulis mengambil judul "Peningkatan Prestasi Belajar PPKn Materi Sistem dan Dinamika Demokrasi dengan Pembelajaran Metode Ceramah Dan Metode Belajar Aktif Dengan Metode Pembelajaran Autentik Pada Siswa Kelas XI.IIS-5 di SMA Negeri 2 Babelan Kabupaten Bekasi Semester I Tahun Pelajaran 2019/2020". Tujuan penelitian ini adalah (1.) Menambah pengetahuan dan wawasan penulis tentang peranan guru PPKn dalam meningkatkan pemahaman siswa belajar PPKn. (2.) Sumbangan pemikiran bagi guru PPKn dalam mengajar dan meningkatkan.

\section{Metode Penelitian}

Tempat penelitian adalah tempat yang digunakan dalam melakukan penelitian untuk memperoleh data yang diinginkan. Penelitian ini bertempat di SMA Negeri 2 Babelan Kabupaten Bekasi tahun pelajaran 2019/2020. Subyek penelitian adalah 35 orang siswa-siswi kelas XI.IIS-5 pada pokok bahasan Sistem dan Dinamika Demokrasi Pancasila.

Waktu penelitian adalah waktu berlangsungnya penelitian atau saat penelitian ini dilangsungkan. Penelitian ini dilaksanakan mulai tanggal 2 September 2019 sampai dengan 2 Oktober 2019 pada semester ganjil tahun pelajaran 2019/2020. 
Sesuai dengan jenis penelitian yang dipilih, yaitu penelitian tindakan, maka penelitian ini menggunakan model penelitian tindakan dari (Arikunto, 2021), yaitu berbentuk spiral dari siklus yang satu ke siklus yang berikutnya. Setiap siklus meliputi planning (rencana), action (tinda-kan), observation (pengamatan), dan reflection (refleksi). Langkah pada siklus berikutnya adalah perncanaan yang sudah direvisi, tindakan, pengamatan, dan refleksi. Sebelum masuk pada siklus 1 dilakukan tindakan pendahuluan yang berupa identifikasi permasalahan. Siklus spiral dari tahap-tahap penelitian tindakan kelas adalah sebagai berikut:

1. Rancangan/rencana awal, sebelum mengadakan penelitian peneliti menyusun rumusan masalah, tujuan dan membuat rencana tindakan, termasuk di dalamnya instrumen penelitian dan perangkat pembelajaran (Jannah, 2021).

2. Kegiatan dan pengamatan, meliputi tindakan yang dilakukan oleh peneliti sebagai upaya membangun pemahaman konsep siswa serta mengamati hasil atau dampak dari diterapkannya pembelajaran metode ceramah dan metode belajar aktif dengan metode pembelajaran autentik (Fahrudin, Zuliana, \& Bintoro, 2018).

3. Refleksi, peneliti mengkaji, melihat dan mempertimbangkan hasil atau dam-pak dari tindakan yang dilakukan berdasarkan lembar pengamatan yang diisi oleh pengamat.

4. Rancangan/rencana yang direvisi, berdasarkan hasil refleksi dari pengamat membuat rancangan yang direvisi untuk dilaksanakan pada siklus berikutnya. Instrumen yang digunakan dalam penelitian ini terdiri dari:

1. Silabus

2. Rencana Pelajaran (RP)

3. Lembar Kegiatan Siswa

4. Tes formatif

Alat pengumpul data dalam penelitian ini adalah tes buatan guru yang fungsinya adalah: (1) untuk menentukan seberapa baik siswa telah menguasai bahan pelajaran yang diberikan dalam waktu tertentu, (2) untuk menentukan apakah suatu tujuan telah tercapai, dan (3) untuk memperoleh suatu nilai (Baharun, 2015). Untuk memperkuat data yang dikumpulkan maka juga digunakan metode observasi (pengamatan) yang dilakukan oleh teman sejawat untuk mengetahui dan merekam aktivitas guru dan siswa dalam proses belajar mengajar (Mariyam, 2021).

Untuk menganalisis tingkat keberhasilan atau persentase keberhasilan siswa setelah proses belajar mengajar setiap putarannya dilakukan dengan cara memberikan evaluasi berupa soal tes tertulis pada setiap akhir putaran (Musyarofah, 2018). Analisis ini dihitung dengan menggunakan statistik sederhana yaitu:

1. Untuk menilai ulangan atau tes formatif

Peneliti melakukan penjumlahan nilai yang diperoleh siswa, dibagi dengan jumlah siswa yang adadan diperoleh rata-rata tes formatif dapat dirumuskan:

$$
H=\frac{\sum X}{\sum N}
$$


Dengan : $\mathrm{X}=$ Nilai rata-rata, $\Sigma \mathrm{X}=$ Jumlah semua nilai, $\Sigma \mathrm{N}=$ Jumlah siswa

2. Untuk ketuntasan belajar

Ada dua kategori ketuntasan belajar yaitu secara perorangan dan secara klasikal. Berdasarkan petunjuk pelaksanaan belajar mengajar kurikulum 2013, yaitu seorang siswa telah tuntas belajar bila telah mencapai skor $70 \%$ atau nilai 70 , dan kelas disebut tuntas belajar bila di kelas tersebut terdapat $85 \%$ yang telah mencapai daya serap lebih dari atau sama dengan 70\% (Masruroh, 2018). Untuk menghitung persentase ketuntasan belajar digunakan rumus sebagai berikut:

$$
P=\frac{\sum \text { Siswa.yang.tuntas.belajar }}{\sum \text { Siswa }} \times 100 \%
$$

Model Gabungan Metode ceramah dan metode belajar aktif dengan metode Pembelajaran autentik dapat meningkatkan pembelajaran PPKn pada Siswa Kelas XI.IIS-5 SMA Negeri 2 Babelan dengan indikator sebagai berikut:

1) Keterampilan guru dalam mengelola pembelajaran PPKn menggunakan Model Gabungan Metode ceramah dan metode belajar aktif dengan metode Pembelajaran autentik meningkat dengan kriteria sekurang-kurangnya baik $(22 \leq$ skor $<33)$.

2) Aktivitas siswa dalam pembelajaran PPKn menggunakan model Gabungan Metode ceramah dan metode belajar aktif dengan metode Pembelajaran autentik meningkat dengan kriteria sekurang-kurangnya baik $(22 \leq$ skor $<33)$.

3) Hasil belajar PPKn dengan menggunakan model Gabungan Metode ceramah dan metode belajar aktif dengan metode Pembelajaran autentik meningkat dengan ketuntasan belajar individual sebesar $(\geq 70)$ dengan ketuntasan klasikal sekurangkurangnya baik $(80 \%)$.

\section{Hasil dan Pembahasan}

Pelaksanaan kegiatan belajar mengajar untuk siklus I dilaksanakan pada hari Selasa tanggal 3 September 2019, siklus II tanggal 17 September 2019, dan siklus III tanggal 1 Oktober 2017 pada kelas XI.IIS-5 dengan jumlah siswa 35 siswa yang semuanya hadir.

Sampai dengan Siklus III, apa yang telah terlaksana dengan baik maupun yang masih kurang baik dalam proses belajar mengajar dengan penerapan gabungan Metode ceramah dan metode belajar aktif dengan metode Pembelajaran autentik. Dari data-data yang telah diperoleh dapat diuraikan sebagai berikut:

1) Selama proses belajar mengajar guru telah melaksanakan semua pembelajaran dengan baik. Meskipun ada beberapa aspek yang belum sempurna, tetapi persentase pelaksanaannya untuk masing-masing aspek cukup besar.

2) Berdasarkan data hasil pengamatan diketahui bahwa siswa aktif selama proses belajar berlangsung. 
3) Kekurangan pada siklus-siklus sebelumnya sudah mengalami perbaikan dan peningkatan sehingga menjadi lebih baik.

4) Hasil belajar siswsa pada siklus III mencapai ketuntasan. Melalui hasil peneilitian ini menunjukkan bahwa gabungan Metode ceramah dan metode belajar aktif dengan metode Pembelajaran autentik memiliki dampak positif dalam meningkatkan prestasi belajar siswa. Hal ini dapat dilihat dari semakin mantapnya pemahaman siswa terhadap materi yang disampaikan guru (ketuntasan belajar meningkat dari siklus I, II, dan III) yaitu masing-masing 62,86\%, 77,14\%, dan 94,29\%. Pada siklus III ketuntasan belajar siswa secara klasikal telah tercapai.

Tabel

Rekapitulasi Hasil Tes Evaluasi Belajar

\begin{tabular}{clccc}
\hline No & \multicolumn{1}{c}{ Uraian } & Siklus II & Siklus II & Siklus III \\
\hline 1 & Nilai rata-rata tes formatif Jumlah & 68,71 & 74,71 & 82,29 \\
2 & siswa yang tuntas belajar & 22 & 27 & 33 \\
3 & Persentase ketuntasan belajar & 62,86 & 77,14 & 94,29 \\
\hline
\end{tabular}

Berdasarkan analisis data, diperoleh aktivitas siswa dalam proses pembelajaran dalam setiap siklus mengalami peningkatan. Hal ini berdampak positif terhadap prestasi belajar siswa yaitu dapat ditunjukkan dengan meningkatnya nilai rata-rata siswa pada setiap siklus yang terus mengalami peningkatan.

Berdasarkan analisis data, diperoleh aktivitas siswa dalam proses pembelajaran PPKn pada pokok bahasan Sistem dan Dinamika Demokrasi Pancasila dengan gabungan metode ceramah dan metode belajar aktif dengan metode pembelajaran autentik yang paling dominan adalah mendengar- kan/memperhatikan penjelasan guru, dan diskusi antar siswa/antara siswa dengan guru. Jadi dapat dikatakan bahwa aktivitas isiwa dapat dikategorikan aktif.

Tabel 2

Hasil Observasi Aktivitas

\begin{tabular}{llccc}
\hline No. & \multicolumn{1}{c}{ Aspek yang Diamati } & $\begin{array}{c}\text { Siklus } \\
\text { I }\end{array}$ & $\begin{array}{c}\text { Siklus } \\
\text { II }\end{array}$ & $\begin{array}{c}\text { Siklus } \\
\text { III }\end{array}$ \\
\hline 1. & Mendengarkan penjelasan teman/ guru & 1 & 2 & 4 \\
\hline 2. & Mengerjakan LKS & 2 & 3 & 4 \\
\hline 3. & Berdiskusi/bertanya dengan teman. & 1 & 2,5 & 3,5 \\
\hline 4. & Bertanya kepada guru. & 2 & 2 & 3 \\
\hline 5. & Penyajian hasil diskusi kelompok. & 1,5 & 2,5 & 3,5 \\
\hline 6. & Menanggapi jawaban teman & 1,5 & 2,5 & 3 \\
\hline 7. & $\begin{array}{l}\text { Menulis/menyalin catatan yang relevan } \\
\text { dengan kegiatan belajar mengajar. }\end{array}$ & 2,5 & 2,5 & 3,5 \\
\hline 8. & $\begin{array}{l}\text { Tidak berada dalam tugas yang meliputi } \\
\text { perca-kapan diluar topik pembelajaran, } \\
\text { mengerjakan sesuatu di luar topik } \\
\text { pembelajaran dan keluar kelas tanpa izin }\end{array}$ & & & \\
\hline
\end{tabular}


Sedangkan untuk aktivitas guru selama pembelajaran telah melaksanakan langkah-langkah belajar aktif dengan baik. Hal ini terlihat dari aktivitas guru yang muncul di antaranya aktivitas membimbing dan mengamati siswa dalam mengerjakan kegiatan LKS/menemukan konsep, menjelas-kan, memberi umpan balik/evaluasi/tanya jawab dimana prosentase untuk aktivitas di atas cukup besar.

Tabel 3

Hasil Observasi Aktivitas Guru

\begin{tabular}{clccc}
\hline \multirow{2}{*}{ No } & \multicolumn{1}{c}{ Kategori pengamatan } & $\begin{array}{c}\text { Siklus } \\
\text { I }\end{array}$ & $\begin{array}{c}\text { Siklus } \\
\text { II }\end{array}$ & $\begin{array}{c}\text { Siklus } \\
\text { III }\end{array}$ \\
\hline 1 & Menyampaikan tujuan & $4.4 \%$ & $6.7 \%$ & $6.7 \%$ \\
\hline 2 & Memotivasi siswa & $8.9 \%$ & $6.7 \%$ & $6.7 \%$ \\
\hline 3 & Mengkaitkan dengan pelajaran sebelumnya & $8.9 \%$ & $6.7 \%$ & $11.1 \%$ \\
\hline 4 & $\begin{array}{l}\text { Menyampaikan materi/ langkah- } \\
\text { langkah/ strategi }\end{array}$ & $6.7 \%$ & $11.1 \%$ & $13.3 \%$ \\
\hline 5 & Menjelaskan materi yang sulit & $13.3 \%$ & $11.1 \%$ & $11.1 \%$ \\
\hline 6 & $\begin{array}{l}\text { Membimbing dan mengamati siswa dalam } \\
\text { menemukan konsep }\end{array}$ & $22.2 \%$ & $24.4 \%$ & $22.2 \%$ \\
\hline 7 & $\begin{array}{l}\text { Meminta siswa menyajikan } \\
\text { dan mendiskusikan hasil }\end{array}$ & $11.1 \%$ & $8.9 \%$ & $11.1 \%$ \\
& $\begin{array}{l}\text { kegiatan } \\
8\end{array}$ & & & \\
\hline 9 & Memberikan umpan balik & $17.8 \%$ & $15.6 \%$ & $13.3 \%$ \\
\hline & Membimbing siswa merangkum pelajaran & $8.9 \%$ & $6.7 \%$ & $11.1 \%$ \\
\hline
\end{tabular}

\section{Kesimpulan}

Dari hasil kegiatan pembelajaran yang telah dilakukan selama tiga siklus, dan berdasarkan seluruh pembahasan serta analisis yang telah dilakukan dapat disimpulkan sebagai berikut: (1.) Pembelajaran dengan gabungan Metode ceramah dan metode belajar aktif dengan metode Pembelajaran autentik memiliki dampak positif dalam meningkatkan prestasi belajar siswa yang ditandai dengan peningkatan ketuntasan belajar siswa dalam setiap siklus, yaitu siklus I $(62,86 \%)$, siklus II $(77,14 \%)$, siklus III (94,29\%). (2.) Penerapan gabungan Metode ceramah dan metode belajar aktif dengan metode Pembelajaran autentik mempunyai pengaruh positif, yaitu dapat mening-katkan motivasi belajar siswa yang ditunjukan dengan rata-rata jawaban siswa hasil wawancara yang menyatakan bahwa siswa tertarik dan berminat dengan gabungan Metode ceramah dan metode belajar aktif dengan metode Pembelajaran autentik sehingga mereka menjadi termotivasi untuk belajar. 


\section{BIBLIOGRAFI}

Arianti, Arianti. (2019). Urgensi Lingkungan Belajar Yang Kondusif Dalam Mendorong Siswa Belajar Aktif. Didaktika: Jurnal Kependidikan, 11(1), 41-62.Google Scholar

Arikunto, Suharsimi. (2021). Penelitian tindakan kelas: Edisi revisi. Jakarta. Bumi Aksara. Google Scholar

Baharun, Hasan. (2015). Penerapan pembelajaran active learning untuk meningkatkan hasil belajar siswa di madrasah. Pedagogik: Jurnal Pendidikan, 1(1). 34-46. Google Scholar

Efansyah, H. Noor. (2018). Meningkatkan Prestasi Belajar Pkn Materi Peran Indonesia Dalam Lingkungan Negara-Negara Di Asia Tenggara Melalui Metode Pengajaran Berbasis Tugas/Proyek Pada Siswa Kelas Vi Sdn Pulau Kuu Kecamatan Muara Uya Kabupatentabalong. Jurnal Langsat, 5(1). 59-62. Google Scholar

Fahrudin, Achmad Gilang, Zuliana, Eka, \& Bintoro, Henry Suryo. (2018). Peningkatan Pemahaman Konsep Matematika melalui Realistic Mathematic Education Berbantu Alat Peraga Bongpas. Anargya: Jurnal Ilmiah Pendidikan Matematika, 1(1), 14-20. Google Scholar

Ichsan, Muhammad. (2016). Psikologi pendidikan dan ilmu mengajar. JURNAL Edukasi: Jurnal Bimbingan Konseling, 2(1), 60-76. Google Scholar

Jannah, Nurul Riyawati. (2021). Meningkatkan Hasil Belajar Materi Beriman Kepada Kitab-Kitab Allah, Mencintai Al-Qur'an Dengan Menggunakan Model Blended Learning Pada Siswa Kelas Viii A Di Smp Negeri 4 Tamban Kabupaten Barito Kuala Tahun Pelajaran 2021/2022. Prosiding Pendidikan Profesi Guru Agama Islam (Ppgai), 1(1), 1502-1510. Google Scholar

Mariyam, Mariyam. (2021). Meningkatkan Prestasi Belajar Keragaman Suku Dan Budaya Indonesia Dengan Metode Bertukar Pasangan Pada Siswa Kelas V Sdn Sumendi Iii Kecamatan Tongas Kabupaten Probolinggo. Pedagogy: Jurnal Ilmiah Ilmu Pendidikan, 8(1), 27-33. Google Scholar

Masruroh, Anik. (2018). Peningkatan Hasil Belajar Bahasa Indonesia Kajian Teks Deskripsi melalui Model Jigsaw Siswa SMP. Jurnal Pendidikan: Riset Dan Konseptual, 2(3), 307-312. Google Scholar

Musyarofah, Atiqatul. (2018). Upaya Peningkatan Motivasi dan Hasil Belajar Pendidikan Agama Islam melalui Metode Inkuiri pada Siswa Kelas XI SMA Negeri 2 Genteng Kabupaten Banyuwangi Tahun Pelajaran 2017/2018. Tarbiyatuna: Kajian Pendidikan Islam, 2(2), 86-96. Google Scholar

Nahar, Novi Irwan. (2016). Penerapan teori belajar behavioristik dalam proses pembelajaran. Nusantara: Jurnal Ilmu Pengetahuan Sosial, 1(1). 64-74. Google 
Ida Panca Rohyani

Scholar

Rostiani, Gita. (2016). Pemanfaatan Lingkungan Sebagai Sumber Belajar Dengan Metode Kontekstual (Contextual Teaching And Learning) Untuk Meningkatkan Aktuvitas Dan Hasil Belajar Siswa Kelas V Dalam Pembelajaran Ips Pada Materi Keragaman Kenampakan Alam. Fkip Unpas. 9 (1).18-27 Google Scholar

Subiyantoro, Rudy. (2021). Peningkatan Prestasi Belajar IPS Pada Materi Interaksi Sosial Melalui Metode Pengajaran Berbasis Proyek Pada Siswa Kelas VII B SMP Negeri 2 Mantup. Jurnal Pengembangan Profesi Pendidik Indonesia, 1(1), 10-17. Google Scholar

Syaparuddin, Syaparuddin, Meldianus, Meldianus, \& Elihami, Elihami. (2020). Strategi pembelajaran aktif dalam meningkatkan motivasi belajar pkn peserta didik. Mahaguru: Jurnal Pendidikan Guru Sekolah Dasar, 1(1), 30-41. Google Scholar

\section{Copyright holder: \\ Ida Panca Rohyani (2021)}

First publication right:

Syntax Idea

This article is licensed under:

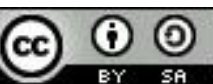

